\title{
Conditioning Affects Growth and Drought Tolerance of Cucurbit Transplants
}

\author{
Joyce G. Latimer ${ }^{1}$ and Reuben B. Beverly ${ }^{1}$ \\ Department of Horticulture, Georgia Station, The University of Georgia, Griffin, GA 30223-1797 \\ Additional index words. cucumber, Cucumis sativus, squash, Cucurbita pepo, watermelon, Citrullus lanatus, brushing, \\ mechanical conditioning, moisture stress, leaf dehydration resistance, growth analysis
}

\begin{abstract}
Brushing (40 strokes per 1.5 minutes, twice daily) or moisture stress conditioning (MSC) (daily nonlethal dry-down cycles) reduced seedling growth of two cucumber (Cucumis sativus L.) cultivars in 1991 and three squash (Cucurbita pepo L.) cultivars in 1991 and 1992. In both years, watermelon [Citrullus lanatus Thunb. (Matsum. \& Nakai)] cultivars varied in responsiveness to brushing; brushing reduced stem length $0 \%$ to $44 \%$ over four cultivars in 1992 . MSC reduced growth of all cultivars. Brushing increased the rate of water loss from detached leaves of cucumber, squash, and watermelon, whereas MSC decreased water loss from leaves of cucumber and squash. In 1991, under well-watered posttransplant conditions, MSC increased the mean relative growth rate (RGR) of cucumber and watermelon transplants in the greenhouse. Brushing increased the RGR of watermelon transplants. In 1992, MSC increased the RGR of squash and watermelon transplants grown under posttransplant drought-stressed conditions, while brushing had no effect. Both conditioning treatments controlled plant growth in the greenhouse without diminishing subsequent plant performance.
\end{abstract}

To meet the physical limitations of shipping containers and automated transplanters, vegetable transplants must be uniform, short, and sturdy (Cantliffe, 1993; Shaw, 1993). Growth regulation of rapidly growing vegetable transplants during greenhouse production is a common problem, especially in the southern U.S. climate. Due to restrictions on using chemical growth regulators on vegetable transplants, developing alternative methods of practical growth control during transplant production is necessary. Growers presently are limited to manipulating temperature or restricting water or fertilizer to control transplant growth.

The purpose of conditioning greenhouse-grown transplants is to control plant growth in a manner that does not reduce the subsequent growth potential of the plant (Latimer, 1990). Ideally, the conditioning treatments would also improve transplant establishment or stress tolerance in the field or final crop yield. However, acceptance of the conditioning treatment for greenhousegrown vegetable transplants depends only on the effectiveness of the growth regulation without a negative impact on subsequent plant performance. Moisture stress conditioning (MSC), the controlled exposure of plants to nonlethal moisture deficits (Eakes et al., 1991), has been moderately successful as an alternative to daminozide for managing the growth of tomato (Lycopersicon esculentum L.) transplants (Latimer, 1992). Mechanical conditioning is a nonchemical means of controlling growth that improves plant strength (Heuchert et al., 1983) and overall transplant quality (Latimer, 1991). Brushing effectively controlled growth of commercially grown tomato transplants (Latimer and Thomas, 1991), but growth and conditioning responses of many other crops are unknown.

With growing interest in brushing as a mechanical means of controlling height during greenhouse transplant production, our research objectives were to determine the responsiveness of cucurbit species and cultivars to brushing or MSC and to evaluate the effectiveness of brushing or MSC in increasing the subsequent

Received for publication 20 Sept. 1993. Accepted for publication 31 Jan. 1994. Special thanks to Sherrod Baden and Allen Byous for technical support of this research. The cost of publishing this paper was defrayed in part by the payment of page charges. Under postal regulations, this paper therefore must be hereby marked advertisement solely to indicate this fact.

${ }^{1}$ Associate professor. drought tolerance of the transplants. The following report describes the effect of brushing or MSC on seedling growth in the greenhouse, dehydration resistance of leaves detached from conditioned plants, and shoot growth rate of plants grown under cyclic drought conditions after transplanting in the greenhouse. Preliminary results of conditioning effects on subsequent yield of the cucurbit transplants grown in the field also are discussed.

\section{Materials and Methods}

Plant culture. Seeds of cucumber, squash, or watermelon were sown directly into flats (cell dimensions, $3.8 \times 3.8 \times 6.0 \mathrm{~cm}$ ) filled with peat-lite seedling medium (Redi-Earth; Grace Horticultural Products, Cambridge, Mass.) in 1991 and 1992 (Table 1). Although seeds of all three squash cultivars were sown in 1992, germination of 'All Seasons' was insufficient for the experiments. Based on uniformity of height and development, seedlings were thinned to one per cell 5 to 7 days after sowing (DAS). Seedlings were fertilized twice weekly with $200 \mathrm{mg}$ N/liter $(20 \mathrm{~N}-8.8 \mathrm{P}$ $16.6 \mathrm{~K})$. Greenhouse temperatures during the experiments averaged 27/19C (day/night), with an average daily photosynthetic photon flux (PPF) of $16.2 \mathrm{~mol} \cdot \mathrm{m}^{-2} \cdot$ day $^{-1}$ in 1991 and 26/20C with $9.3 \mathrm{~mol} \cdot \mathrm{m}^{-2} \cdot$ day $^{-1} \mathrm{PPF}$ in 1992 .

Each vegetable species constituted a separate experiment using a strip-plot design with three replications. Cultivar was the main plot and conditioning treatments were subplots. Treatments consisted of brushing initiated at the cotyledonary leaf stage, MSC, and an untreated control (Table 1). A brushing apparatus was designed to apply the treatment uniformly across cultivars (Baden and Latimer, 1992). Individual flats of brushed plants were elevated with wooden slats to maintain plants of different cultivars at a uniform canopy height. The upper 5 to $10 \mathrm{~cm}$ of the transplants were brushed with a wooden pole at 40 strokes per 1.5 min twice daily. For MSC, we withheld water until the seedlings exhibited visible wilt symptoms for $\approx 2 \mathrm{~h}$ daily (Latimer, 1992). The other plants were watered well. Treatments continued until transplanting (Table 1), at which time we randomly selected six plants per replication for growth measurement. Data included number of leaves $>1 \mathrm{~cm}$ long, leaf area measured with a leaf area meter (LI-3000; LI-COR, Lincoln, Neb.), stem length, and shoot dry weight after $72 \mathrm{~h}$ at $70 \mathrm{C}$ in a forced-air oven. The length of the 
Table 1. Cultivars tested, initiation times of conditioning treatments [days after sowing (DAS)], and transplant (to field or greenhouse cup; also corresponds to date of growth or dehydration measurements) and yield measurement dates of cucurbits in 1991 and 1992.

\begin{tabular}{|c|c|c|c|c|c|}
\hline \multirow[b]{2}{*}{ Cultivar } & \multirow{2}{*}{$\begin{array}{l}\text { Date } \\
\text { sown }\end{array}$} & \multicolumn{2}{|c|}{ Initiation (DAS) } & \multirow{2}{*}{$\begin{array}{c}\text { Date } \\
\text { planted }\end{array}$} & \multirow[b]{2}{*}{ Harvest period } \\
\hline & & Brushing & $\mathrm{MSC}^{\mathrm{z}}$ & & \\
\hline \multicolumn{6}{|c|}{1991} \\
\hline \multicolumn{6}{|l|}{ Cucumber } \\
\hline $\begin{array}{l}\text { Sweet Success } \\
\text { Suyo Long }\end{array}$ & 24 Apr. & 8 & 13 & 16 May & 14 June to 22 Aug. \\
\hline \multicolumn{6}{|l|}{ Squash } \\
\hline $\begin{array}{l}\text { All Seasons } \\
\text { Cream of the Crop } \\
\text { Dixie }\end{array}$ & 23 Apr. & 7 & 14 & 8 May & 4 June to 8 Aug. \\
\hline \multicolumn{6}{|l|}{ Watermelon } \\
\hline $\begin{array}{l}\text { Sweet Favorite } \\
\text { Sugar Baby }\end{array}$ & 24 Apr. & 9 & 12 & 23 May & 1 to 22 Aug. \\
\hline \multicolumn{6}{|c|}{1992} \\
\hline Squash & & & & & \\
\hline $\begin{array}{l}\text { Cream of the Crop } \\
\text { Dixie }\end{array}$ & 6 May & 9 & 11 & 21 May & 18 June to 24 Aug. \\
\hline Watermelon & & & & & \\
\hline $\begin{array}{l}\text { Sweet Favorite } \\
\text { Sugar Baby } \\
\text { Crimson Sweet } \\
\text { Starbrite }\end{array}$ & 1 May & 8 & 13 & 29 May & 11 to 24 Aug. \\
\hline
\end{tabular}

petiole of the first true leaf of cucumber and squash plants also was measured in 1991.

Dehydration of detached leaves. We selected one cultivar of each species for evaluating posttransplant stress tolerance. At transplanting time, six (1991) or five (1992) plants from each replication were randomly selected for evaluating the dehydration rate of a detached leaf. For acclimation to test conditions, the plants were moved to the test site the evening before measurement. We tested each species on a separate day. In 1991, laboratory temperatures were maintained at $24 \mathrm{C}$ and relative humidity ranged from $59 \%$ to $64 \%$. In 1992, the test was conducted in a controlledenvironment room at $25 \mathrm{C}$ and $40 \%$ relative humidity. Due to limited availability of the room, only squash was evaluated.

Leaves of uniform development, the most recently expanded mature leaf, were selected for detachment. The petiole was severed from the plant $\approx 2.5 \mathrm{~cm}$ from the base of the leaf. Leaves were handled only by the petiole and placed adaxial side up on the benchtop. Initial fresh weights were measured immediately after detachment, and each leaf was subsequently weighed $15,30,45$, $60,120,180$, and $240 \mathrm{~min}$ after detachment. Data are expressed as cumulative water loss per gram of leaf dry weight.

Posttransplant growth rate in greenhouse. At the end of the conditioning period, 40 uniform plants from each treatment were selected for evaluating growth rate after transplanting. In 1991, seedlings were planted in 0.9-liter styrofoam cups (with perforated bottoms) filled with medium-grade sand ( 2 to $4 \mathrm{~mm} ; 0.21 \mathrm{~g} \mathrm{H}_{2} \mathrm{O}$ / $\mathrm{g}$ sand at field capacity). All plants were watered daily with $50 \mathrm{mg}$ $\mathrm{N} /$ liter. Pots were arranged in a randomized complete-block design in the greenhouse, maintaining the three replications from the previous experiment. Plants were harvested at 3-day intervals to calculate rates of shoot dry weight gain.

In 1992, 20 plants from each conditioning treatment were assigned to unstressed or drought-stressed posttransplant conditions. A coarse sand ( 5 to $12 \mathrm{~mm} ; 0.13 \mathrm{~g} \mathrm{H}_{2} \mathrm{O} / \mathrm{g}$ sand at field capacity) was used for both treatments, and unstressed plants were watered daily to maintain a maximum pot weight of $\approx 95 \%$ container capacity. The stressed treatment was watered to saturation every 2 to 3 days when the pot reached $\approx 90 \%$ container capacity. This level of stress caused moderate to severe wilting. However, we observed no visible dehydration damage in any crop.

Field culture. Each year, plots (Cecil sandy loam soil, Typic Halpludult) measured $1 \mathrm{~m}$ long $\times 0.5 \mathrm{~m}$ wide in a radial garden design (Beverly, 1993). Plots were fertilized before planting with $27 \mathrm{~g} 13 \mathrm{~N}-5.7 \mathrm{P}-10.8 \mathrm{~K}$ per $\mathrm{m}$, sidedressed with $5 \mathrm{~g}$ ammonium nitrate per $\mathrm{m}$ of row, mulched with straw to a depth of $10 \mathrm{~cm}$, and irrigated by a drip irrigation tube down the center of the plot. Cultivar $\times$ conditioning treatment combinations were randomly assigned to plots. Two plants of each cultivar were transplanted to each plot with three replications. Mature fruit were harvested up to twice weekly (Table 1).

Statistical analysis. All data were subjected to analysis of variance or regression analysis using SAS's general linear models procedure (Littell et al., 1991), and mean separation was by Duncan's multiple range test, $P<0.05$. Slopes and intercepts were compared by paired $t$ tests, $P<0.05$. Mean relative growth rates (RGRs) were determined as the slope estimates of regression of the ln shoot dry weight over time after transplanting (Radford, 1967).

\section{Results and Discussion}

Cucurbit transplant growth. Due to significant interactions between cultivars and conditioning treatments in all crops, data were analyzed separately for each cultivar. Conditioning treatments generally reduced the growth of greenhouse-grown cucurbit transplants (Table 2). Brushing or MSC delayed plant development of both cucumber cultivars as indicated by a reduced number of leaves. Brushing or MSC reduced leaf area, petiole length (first leaf), stem length, and shoot dry weight of cucumber transplants. 
Table 2. Effect of brushing or moisture stress conditioning (MSC) on growth of cucurbit transplants grown in the greenhouse. See Table 1 for treatment periods.

\begin{tabular}{|c|c|c|c|c|c|}
\hline $\begin{array}{l}\text { Cultivar } \\
\text { and } \\
\text { treatment }\end{array}$ & $\begin{array}{c}\text { No. } \\
\text { of } \\
\text { leaves }\end{array}$ & $\begin{array}{l}\text { Leaf } \\
\text { area } \\
\left(\mathrm{cm}^{2}\right)\end{array}$ & $\begin{array}{l}\text { Petiole } \\
\text { length } \\
(\mathrm{cm})\end{array}$ & $\begin{array}{l}\text { Stem } \\
\text { length } \\
(\mathrm{cm})\end{array}$ & $\begin{array}{c}\text { Shoot } \\
\text { dry wt } \\
(\mathrm{mg})\end{array}$ \\
\hline & & 1991 & & & \\
\hline \multicolumn{6}{|l|}{ Cucumber } \\
\hline \multicolumn{6}{|c|}{ Sweet Success } \\
\hline Untreated & $3.0 \mathrm{a}^{\mathrm{z}}$ & $121 \mathrm{a}$ & $10.2 \mathrm{a}$ & $26.6 \mathrm{a}$ & $457 \mathrm{a}$ \\
\hline Brushed & $2.6 \mathrm{~b}$ & $84 \mathrm{~b}$ & $8.0 \mathrm{~b}$ & $20.5 \mathrm{~b}$ & $352 \mathrm{~b}$ \\
\hline MSC & $2.4 \mathrm{~b}$ & $65 \mathrm{c}$ & $5.0 \mathrm{c}$ & $18.5 \mathrm{c}$ & $260 \mathrm{c}$ \\
\hline \multicolumn{6}{|l|}{ Suyo Long } \\
\hline Untreated & $3.1 \mathrm{a}$ & $82 \mathrm{a}$ & $12.0 \mathrm{a}$ & $23.0 \mathrm{a}$ & $340 \mathrm{a}$ \\
\hline Brushed & $2.6 \mathrm{~b}$ & $57 \mathrm{~b}$ & $7.7 \mathrm{~b}$ & $16.0 \mathrm{~b}$ & $286 \mathrm{~b}$ \\
\hline MSC & $2.4 \mathrm{~b}$ & $57 \mathrm{~b}$ & $6.2 \mathrm{c}$ & $14.0 \mathrm{c}$ & $264 \mathrm{~b}$ \\
\hline \multicolumn{6}{|l|}{ Squash } \\
\hline \multicolumn{6}{|l|}{ All Seasons } \\
\hline Untreated & $2.0 \mathrm{a}$ & $88 \mathrm{a}$ & $10.5 \mathrm{a}$ & $7.0 \mathrm{a}$ & $338 \mathrm{a}$ \\
\hline Brushed & $2.0 \mathrm{a}$ & $74 \mathrm{~b}$ & $7.0 \mathrm{~b}$ & $6.0 \mathrm{~b}$ & $295 \mathrm{a}$ \\
\hline MSC & $2.1 \mathrm{a}$ & $78 \mathrm{ab}$ & $10.3 \mathrm{a}$ & $7.0 \mathrm{a}$ & $294 \mathrm{a}$ \\
\hline \multicolumn{6}{|c|}{ Cream of the Crop } \\
\hline Untreated & $2.1 \mathrm{a}$ & $80 \mathrm{a}$ & $13.3 \mathrm{a}$ & $7.3 \mathrm{a}$ & $258 \mathrm{a}$ \\
\hline Brushed & $2.0 \mathrm{a}$ & $72 \mathrm{a}$ & $7.0 \mathrm{c}$ & $5.5 \mathrm{c}$ & $238 \mathrm{a}$ \\
\hline MSC & $2.1 \mathrm{a}$ & $73 \mathrm{a}$ & $10.6 \mathrm{~b}$ & $6.5 \mathrm{~b}$ & $231 \mathrm{a}$ \\
\hline \multicolumn{6}{|l|}{ Dixie } \\
\hline Untreated & $2.6 \mathrm{a}$ & $76 \mathrm{a}$ & $14.3 \mathrm{a}$ & $9.6 \mathrm{a}$ & $312 \mathrm{a}$ \\
\hline Brushed & $2.3 \mathrm{a}$ & $57 \mathrm{~b}$ & $8.0 \mathrm{c}$ & $8.0 \mathrm{~b}$ & $262 b$ \\
\hline \multirow[t]{2}{*}{ MSC } & $2.3 \mathrm{a}$ & $82 \mathrm{a}$ & $12.8 \mathrm{~b}$ & $9.1 \mathrm{a}$ & $294 \mathrm{a}$ \\
\hline & & 1992 & & & \\
\hline \multicolumn{6}{|l|}{ Watermelon } \\
\hline \multicolumn{6}{|c|}{ Sweet Favorite } \\
\hline Untreated & $3.1 \mathrm{a}$ & $57 \mathrm{a}$ & --- & $4.8 \mathrm{a}$ & $287 \mathrm{a}$ \\
\hline Brushed & $3.1 \mathrm{a}$ & $52 \mathrm{a}$ & --- & $4.9 \mathrm{a}$ & $288 \mathrm{a}$ \\
\hline MSC & $3.1 \mathrm{a}$ & $35 \mathrm{~b}$ & --- & $5.1 \mathrm{a}$ & $201 \mathrm{~b}$ \\
\hline \multicolumn{6}{|l|}{ Sugar Baby } \\
\hline Untreated & $4.2 \mathrm{a}$ & $78 \mathrm{a}$ & --- & $8.7 \mathrm{a}$ & $397 \mathrm{a}$ \\
\hline Brushed & $4.1 \mathrm{a}$ & $73 \mathrm{a}$ & --- & $6.1 \mathrm{~b}$ & $392 \mathrm{a}$ \\
\hline MSC & $3.3 \mathrm{~b}$ & $38 \mathrm{~b}$ & --- & $5.4 \mathrm{c}$ & $241 \mathrm{~b}$ \\
\hline \multicolumn{6}{|c|}{ Crimson Sweet } \\
\hline Untreated & $4.8 \mathrm{a}$ & $97 \mathrm{a}$ & --- & $12.8 \mathrm{a}$ & $473 \mathrm{a}$ \\
\hline Brushed & $4.1 \mathrm{~b}$ & $74 \mathrm{~b}$ & --- & $7.0 \mathrm{~b}$ & $381 \mathrm{~b}$ \\
\hline MSC & $3.7 \mathrm{c}$ & $46 \mathrm{c}$ & --- & $7.1 \mathrm{~b}$ & $266 \mathrm{c}$ \\
\hline \multicolumn{6}{|l|}{ Starbrite } \\
\hline Untreated & $5.2 \mathrm{a}$ & $102 \mathrm{a}$ & --- & $12.8 \mathrm{a}$ & $481 \mathrm{a}$ \\
\hline Brushed & $5.3 \mathrm{a}$ & $93 \mathrm{~b}$ & --- & $8.6 \mathrm{~b}$ & $471 \mathrm{a}$ \\
\hline MSC & $4.4 \mathrm{~b}$ & $63 c$ & --- & $8.4 \mathrm{~b}$ & $357 \mathrm{~b}$ \\
\hline
\end{tabular}

${ }^{\mathrm{z}}$ Mean separation within columns and by cultivars by Duncan's multiple range test at $P=0.05$.

For squash transplants in 1991, conditioning did not affect the number of leaves, but brushing reduced leaf area (except for 'Cream of the Crop') and petiole and stem length. Brushing reduced shoot dry weight only for 'Dixie'. Squash transplants were subjected to only one MSC episode before growth was measured, which accounts for the general lack of response to MSC.

Although 'Cream of the Crop' and 'Dixie' squash transplants were similar in overall growth and vigor, the cultivars responded differently to conditioning in 1992 . Whereas brushing reduced stem length of 'Dixie' (untreated 7.3 a, brushed 6.1 b, MSC 6.6 b), as it did for all three cultivars in 1991, brushing resulted in a slightly greater final stem length of 'Cream of the Crop' transplants in 1992 (untreated $5.1 \mathrm{~b}$, brushed $5.8 \mathrm{a}$, MSC $5.4 \mathrm{ab}$ ). The 5 days of MSC in 1992 decreased the number of leaves and leaf area of both cultivars (data not presented). Conditioning did not reduce shoot dry weight (data not presented).

Since 'Sweet Favorite' and 'Sugar Baby' watermelon transplants responded to conditioning in the same manner both years, only 1992 data are presented. 'Sweet Favorite' was the least vigorous of the four cultivars and exhibited no response to brushing and the least response to MSC (Table 2). Brushing did not affect number of leaves, leaf area, or shoot dry weight of 'Sugar Baby' transplants, but reduced stem length $30 \%$ relative to untreated plants. 'Crimson Sweet' and 'Starbrite' are more vigorous than either of the cultivars used in 1991 and both were more responsive to brushing than 'Sugar Baby'. 'Crimson Sweet' was 
the most responsive of the tested cultivars to both conditioning treatments. Brushing, and MSC to a greater extent, reduced leaf development, leaf area, and shoot dry weight of 'Crimson Sweet' transplants. MSC delayed leaf development of all cultivars except 'Sweet Favorite' and reduced all growth parameters measured for all cultivars except 'Sweet Favorite' stem length.

These growth responses are consistent with previous reports on the effects of brushing and MSC, including the differences in cultivar response to a uniform brushing treatment (Latimer et al., 1991). Conditioning improved the compactness of the cucumber and squash transplants by reducing stem growth and final petiole length. Untreated 'Crimson Sweet' plants had a more loose and weak (tangled) appearance compared to conditioned plants, while the compactness of the other watermelon cultivars was only slightly improved by conditioning. Salvia (Salvia splendens F. Sellow) plants subjected to MSC for four dry-down cycles were smaller and more attractive, with greater drought tolerance than untreated plants (Eakes et al., 1991)

Dehydration of detached leaves. Cumulative water loss was linear over the 6-h measurement period (Fig. 1), a result indicating that we measured cuticular water loss. In 1991, detached leaves of the brushed transplants of all three crops had the greatest dehydration rate (Fig. 1). The rate of water loss (slope of the regression line) from the detached leaf of brushed squash plants was $275 \%$ that of the untreated leaf. Cumulative water loss from detached cucumber and watermelon leaves was significantly, but less drastically, increased by brushing. Leaves from brushed squash plants in 1992 responded as shown in Fig. 1, with total cumulative water loss $200 \%$ greater than that of leaves from untreated plants (data not presented).

In the cucumber and squash experiments, MSC decreased the dehydration rate of the detached leaf (Fig. 1), a result indicating increased drought tolerance. However, the squash MSC treatment consisted of only one drought cycle. Therefore, with additional drought cycles in 1992, we expected MSC to enhance squash leaf tolerance to dehydration (Ackerson, 1980). However, in 1992, there was no difference in the slopes or intercepts of the regression equations for cumulative water loss of leaves from untreated or MSC plants (data not presented). Similarly, MSC did not affect the rate of water loss of detached leaves of watermelon plants in 1991. High levels of dehydration resistance are associated with superior drought resistance of whole plants of various wheat (Triticum aestivum L.) cultivars (Dedio, 1975). Mechanical stress via stem rubbing reduced the water loss of subsequently detached leaves of kidney beans (Phaseolus vulgaris L.), thereby increasing the dehydration resistance of the treated plants (Suge, 1980). Stem rubbing also increased the subsequent tolerance of kidney beans to severe drought stress (Jaffe and Biro, 1979; Suge, 1980). However, stem rubbing does not physically abrade leaves as brushing may.

Posttransplant growth rate in greenhouse. In 1991, under unstressed conditions, brushing did not delay resumption of growth of cucumber transplants; the mean RGR of brushed transplants was not different from that of the untreated transplants (Table 3). However, cucumber transplants subjected to MSC resumed growth more quickly after transplanting with a growth rate greater than that of the untreated transplants. Conditioning had no effect on the RGR of transplanted squash plants. Only for watermelon did brushing improve subsequent transplant growth. However, brushing reduced only the stem length of 'Sugar Baby' watermelon transplants; shoot dry weight and leaf area were not reduced relative to the untreated controls. MSC increased posttransplant RGR compared to that of untreated or brushed watermelon transplants.

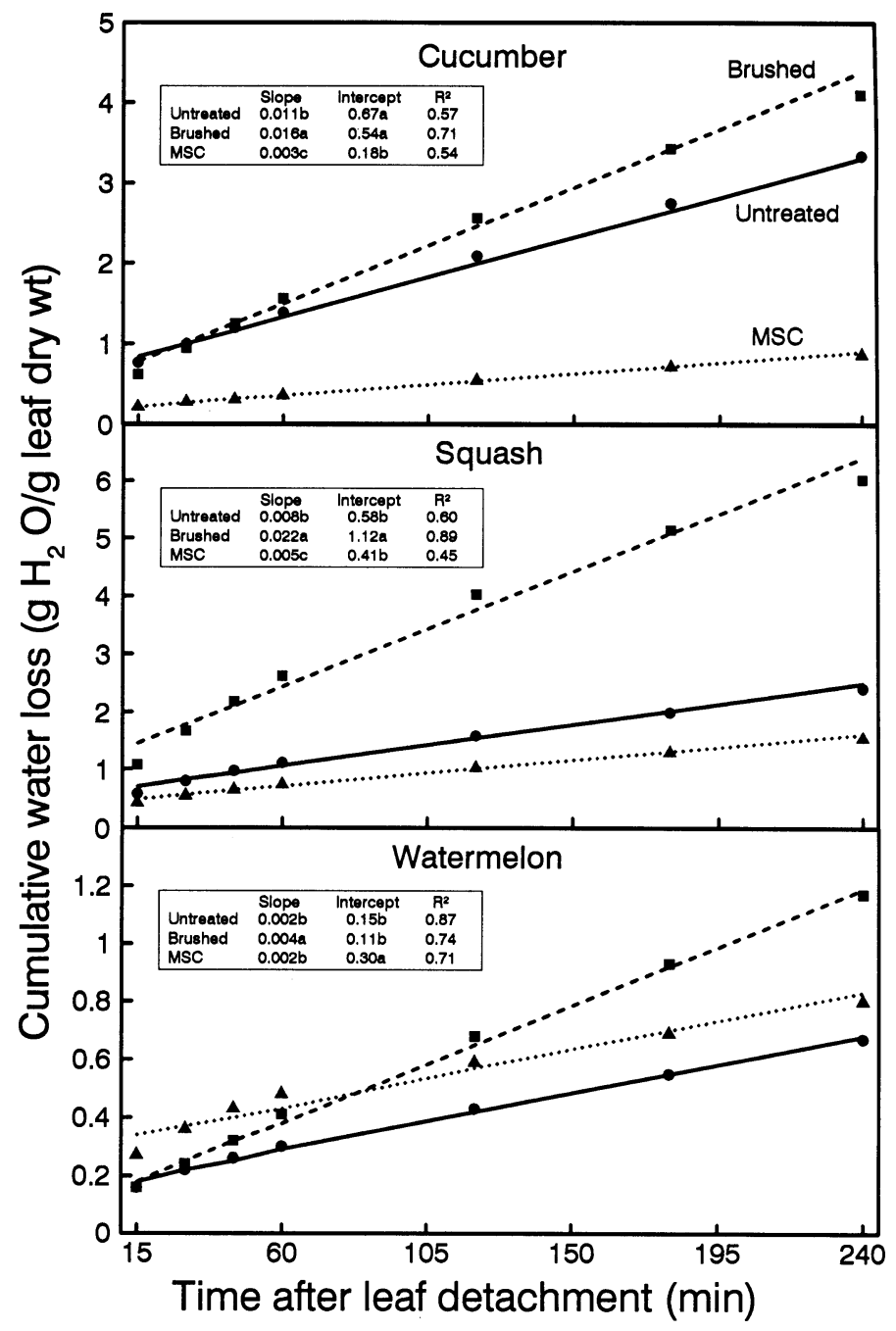

Fig. 1. Cumulative water loss from detached leaves of untreated or conditioned transplants of 3-week-old 'Suyo Long' cucumber, 2-week-old 'Dixie' squash, or

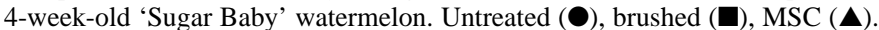
Comparisons of coefficient estimates were by paired $t$ tests, $P<0.05$.

Table 3. Regression equations describing shoot dry weight as a function of days after transplanting (DAT) under unstressed greenhouse conditions (1991).

\begin{tabular}{|c|c|c|c|}
\hline Treatment & $\begin{array}{l}\text { Regression } \\
\text { equation }^{z}\end{array}$ & $R^{2}$ & $\begin{array}{c}\text { Mean } \\
\text { relative } \\
\text { growth } \\
\text { rate }\end{array}$ \\
\hline \multicolumn{4}{|c|}{ Suyo Long cucumber } \\
\hline Untreated & LSHDW $=5.91+0.076 x$ & 0.60 & $0.076 b^{3}$ \\
\hline Brushed & LSHDW $=5.71+0.069 x$ & 0.58 & $0.069 \mathrm{~b}$ \\
\hline \multicolumn{4}{|c|}{ Dixie squash } \\
\hline Untreated & LSHDW $=5.66+0.136 x$ & 0.73 & $0.136 \mathrm{a}$ \\
\hline Brushed & LSHDW $=5.53+0.132 x$ & 0.74 & $0.132 \mathrm{a}$ \\
\hline \multicolumn{4}{|c|}{ Sugar Baby watermelon } \\
\hline Untreated & LSHDW $=6.20+0.063 x$ & 0.76 & $0.063 \mathrm{c}$ \\
\hline Brushed & $\mathrm{LSHDW}=6.19+0.075 \mathrm{x}$ & 0.87 & $0.075 \mathrm{~b}$ \\
\hline MSC & LSHDW $=5.39+0.114 x$ & 0.92 & $0.114 \mathrm{a}$ \\
\hline
\end{tabular}

${ }^{\mathrm{z}} \mathrm{LSHDW}=$ natural log-transformed shoot dry weight $(\mathrm{mg}) ; \mathrm{x}=\mathrm{DAT}$. ${ }^{\mathrm{y}}$ Coefficients tested by paired $t$ tests, $P<0.05$.

${ }^{\mathrm{x}} \mathrm{MSC}=$ moisture stress conditioning. 
In 1992, drought-stressed posttransplant conditions reduced growth of all transplants relative to those subjected to the same conditioning treatment and grown under unstressed posttransplant conditions ( $t$ test, $P<0.05$ ). Therefore, we examined the effects of conditioning treatments within each posttransplant environment. Under unstressed posttransplant conditions, prior conditioning treatments had no effect on the growth rate of squash transplants (Fig. 2a), a result consistent with the 1991 data. Under stressed posttransplant conditions, only MSC accelerated growth after transplanting (Fig. 2b). Contrary to 1991, brushing in 1992 did not improve the posttransplant growth of watermelon plants under unstressed conditions (Fig. 3a). However, MSC improved growth of watermelon transplants under unstressed (Fig. 3a) and droughtstressed posttransplant conditions (Fig. 3b), in spite of significant reductions in plant development before transplanting (Table 2).

The effects of drought on plant water relations and stomatal physiology have been documented well (Zeiger et al., 1987). Plants conditioned by drought are able to continue to grow by maintaining open stomata to achieve lower leaf water potentials than untreated plants (Cutler and Rains, 1977). As a result, growth of MSC transplants in the current study was not as limited by the stressed posttransplant conditions as was that of the untreated plants. Drought conditioning or hardening is a common practice before field-planting vegetable transplants, but the improvement in subsequent field establishment is inconsistent and overhardening can reduce crop yields (McKee, 1981; Orzolek, 1991).

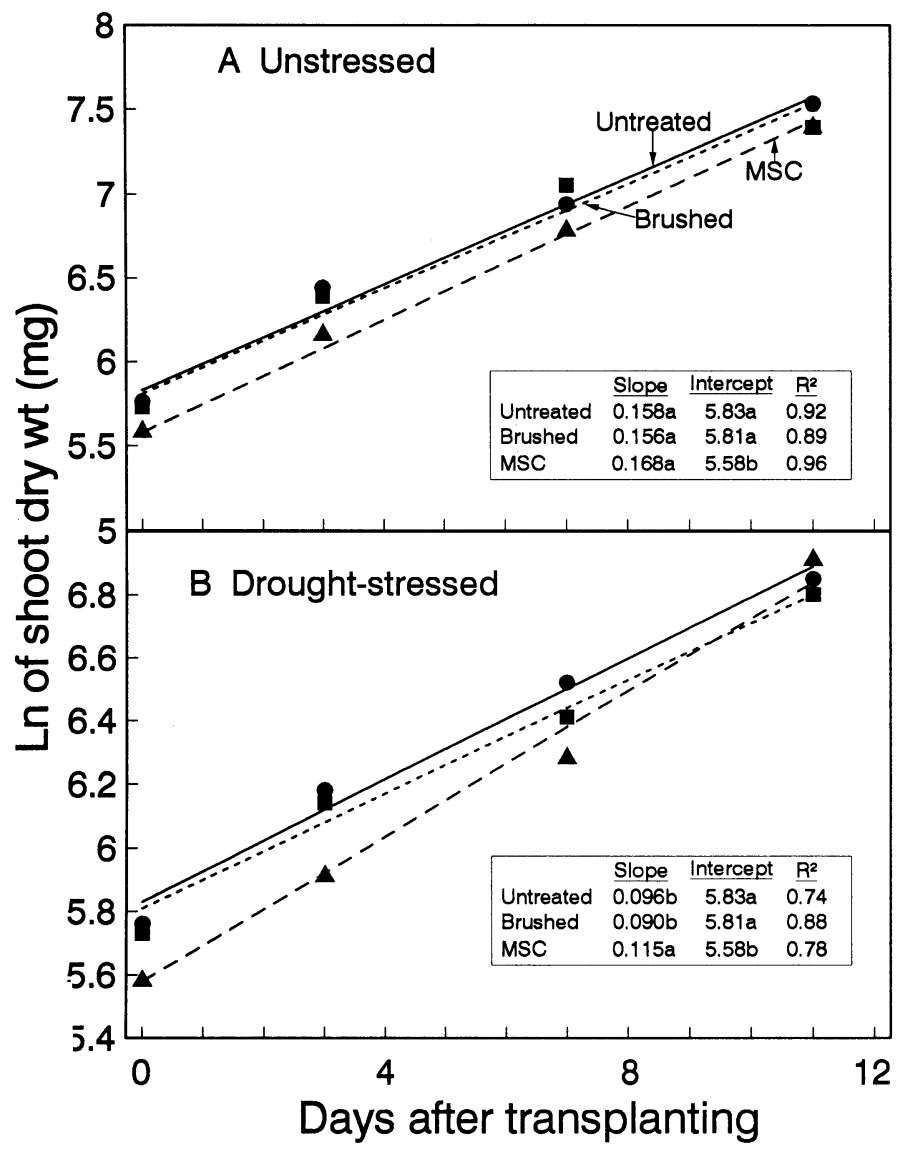

Fig. 2. Natural log transformation of shoot dry weight of 'Dixie' squash plants (1992) maintained under (A) unstressed (well-watered) conditions or (B) droughtstressed conditions measured over days after transplanting. Untreated (O), brushed $(\boldsymbol{\square})$, MSC $(\boldsymbol{\Delta})$. Comparisons of coefficient estimates were by paired $t$ tests, $P<0.05$
Subsequent field production. Plant mortality in some plots necessitated normalizing yields to plant populations in 1991. These losses resulted in a minimum of three plants per treatment for 'Sweet Success' cucumber and 'All Seasons' squash. Plant mortality was not associated with conditioning treatments. All plants survived to yield fruit in 1992. Due to the small plant numbers used in the field tests in both years, the yield data are considered preliminary. There were no significant $(P>0.05)$ conditioning treatment effects on total fruit weight per plant, number of fruit per plant, or the mean weight per fruit of any cucumber or watermelon cultivar in 1991 or squash cultivar in 1991 or 1992. In 1992, watermelon cultivars did not differ in yield characteristics. However, MSC reduced subsequent fruit weight per plant $50 \%$ relative to untreated plants $(17.0 \mathrm{~kg} / \mathrm{plant}$ for untreated vs. $8.6 \mathrm{~kg} /$ plant for MSC, $P<0.05, \mathrm{n}=24)$. Brushing had no effect on watermelon yield characteristics. Drought-conditioning tomato improved field establishment of the transplants without affecting fruit yield or individual fruit weight (Latimer, 1992), a result suggesting that crop responses to MSC depend on species, with differences in cultivars also likely.

\section{Conclusions}

Although cultivar differences exist, cucumber, squash, and watermelon are responsive to brushing initiated at the cotyledonary stage, exhibiting moderate height control, very little leaf

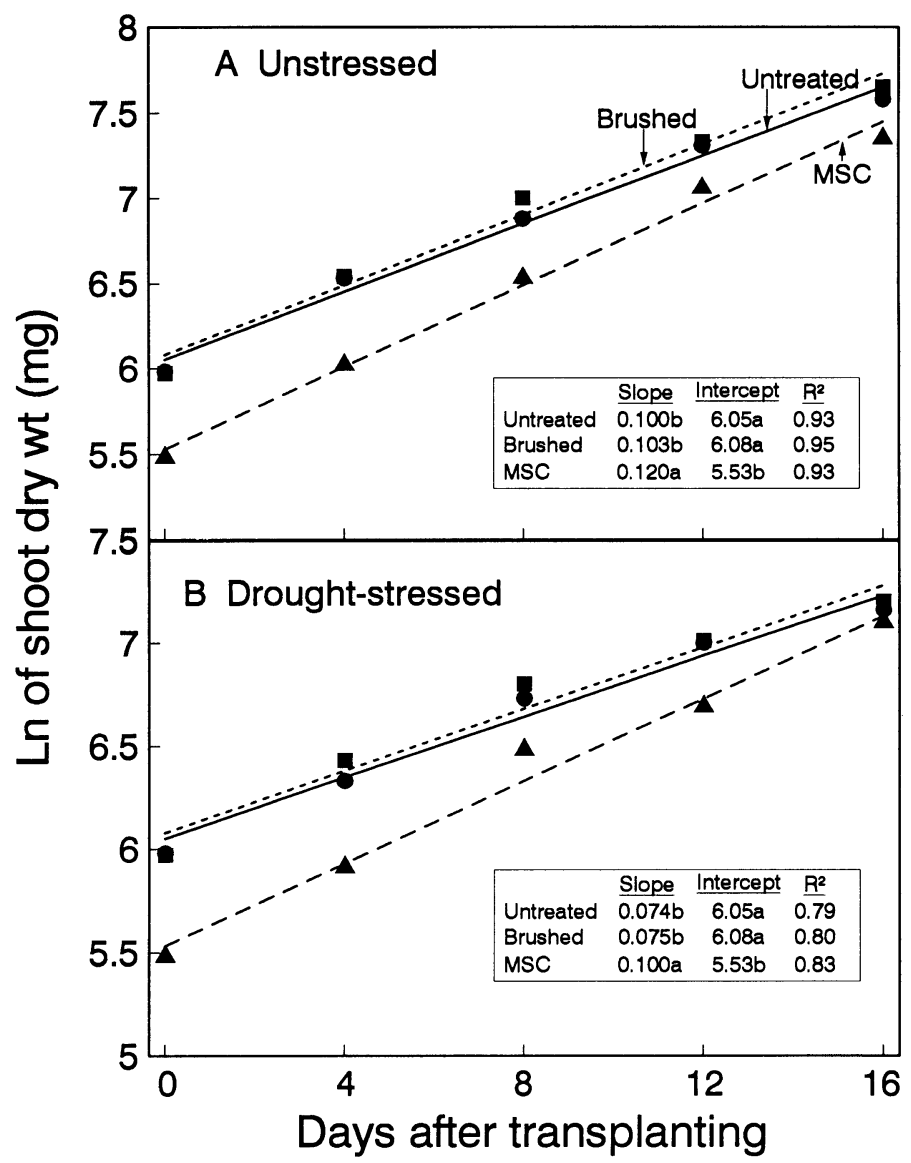

Fig. 3. Natural log transformation of shoot dry weight of 'Sugar Baby' watermelon plants (1992) maintained under (A) unstressed (well-watered) conditions or (B) drought-stressed conditions measured over days after transplanting. Untreated $(\boldsymbol{O})$, brushed $(\boldsymbol{\square}), \operatorname{MSC}(\boldsymbol{\Delta})$. Comparisons of coefficient estimates were by paired $t$ tests, $P<0.05$. 
damage, and no deleterious effects on yield. In agreement with previous reports (Latimer et al., 1991), brushing resulted in greater reductions in growth of transplants of the more vigorous cultivars within each species. Although brushing shows good potential as a nonchemical method of controlling the growth of greenhouse-grown cucurbit transplants, it does not generally improve their drought tolerance. Results from studies on dehydration of detached leaves strongly suggest that brushing would be detrimental to transplant survival. However, the other effects of brushing apparently ameliorate this lack of control of cuticular water loss. Relative to untreated plants, brushed transplants did not exhibit reduced growth rate under subsequent unstressed or drought-stressed conditions for any of the three crops.

MSC also reduced plant growth in the greenhouse and reduced the loss of water from detached leaves of all three crops. Managing drought stress in the greenhouse is difficult. Maintaining a regular cyclic drought for small plants is difficult, while the potential for excessive stress of large transplants is high. MSC increased the subsequent RGR of cucumber and watermelon under unstressed posttransplant conditions and of squash and watermelon under drought-stressed conditions, relative to that of untreated plants. However, yield reductions for MSC watermelon transplants were significant. Limiting MSC to crop species identified as drought-tolerant would improve the safety of using this method for nonchemical growth regulation in the greenhouse.

Conditioning by either brushing or MSC generally provided the growth regulation necessary for producing cucurbits in the greenhouse without reducing subsequent drought tolerance or crop yield. Combining MSC and brushing may provide a better conditioned transplant than using either method alone. Using these techniques, it may be possible to produce a transplant that is shorter and stronger with improved drought tolerance and growth resumption that will yield at least as well as untreated plants.

\section{Literature Cited}

Ackerson, R.C. 1980. Stomatal response of cotton to water stress and abscisic acid as affected by water stress history. Plant Physiol. 65:455459.

Baden, S.A. and J.G. Latimer. 1992. An effective system for brushing vegetable transplants for height control. HortTechnology 2:412-414.

Beverly, R.B. 1993. ASTER garden: A novel vegetable garden design for international development. HortScience 28:690,763.
Cantliffe, D.J. 1993. Pre- and postharvest practices for improved vegetable transplant quality. HortTechnology 3:415-418.

Cutler, J.M. and D.W. Rains. 1977. Effects of irrigation history on responses of cotton to subsequent water stress. Crop Sci. 17:329-335.

Dedio, W. 1975. Water relations in wheat leaves as screening tests for drought resistance. Can. J. Plant Sci. 55:369-378.

Eakes, D.J., R.D. Wright, and J.R. Seiler. 1991. Moisture stress conditioning effects on Salvia splendens 'Bonfire'. J. Amer. Soc. Hort. Sci. 116:716-719.

Heuchert, J.C., J.S. Marks, and C.A. Mitchell. 1983. Strengthening of tomato shoots by gyratory shaking. J. Amer. Soc. Hort. Sci. 108:801805.

Jaffe, M.J. and R. Biro. 1979. Thigmomorhogenesis: The effect of mechanical perturbation on the growth of plants, with special reference to anatomical changes, the role of ethylene, and interaction with other environmental stresses, p. 25-59. In: H. Mussell and R.C. Staples (eds.). Stress physiology in crop plants. Wiley, New York.

Latimer, J.G. 1990. Drought or mechanical stress affects broccoli transplant growth but not yield. HortScience 25:1233-1235.

Latimer, J.G. 1991. Mechanical conditioning for control of growth and quality of vegetable transplants. HortScience 26:1456-1461.

Latimer, J.G. 1992. Drought, paclobutrazol, abscisic acid, and gibberellic acid as alternatives to daminozide in tomato transplant production. J. Amer. Soc. Hort. Sci. 117:243-247.

Latimer, J.G., T. Johjima, and K. Harada. 1991. The effect of mechanical stress on transplant growth and subsequent yield of four cultivars of cucumber. Scientia Hort. 47:221-230.

Latimer, J.G. and P.A. Thomas. 1991. Application of brushing for growth control of tomato transplants in a commercial setting. HortTechnology $1: 109-110$.

Littell, R.C., F.J. Freund, and P.C. Spector. 1991. SAS system for linear models. SAS Inst., Cary, N.C.

McKee, J.M.T. 1981. Physiological aspects of transplanting vegetables and other crops. II. Methods used to improve transplant establishment. Hort. Abstr. 51:355-368.

Orzolek, M.D. 1991. Establishment of vegetables in the field. HortTechnology 1:78-81.

Radford, P.J. 1967. Growth analysis formulae-Their use and abuse. Crop Sci. 7:171-175.

Shaw, L.N. 1993. Changes needed to facilitate automatic transplanting. HortTechnology 3:418-420.

Suge, H. 1980. Dehydration and drought resistance in Phaseolus vulgaris as affected by mechanical stress. Rpt. Inst. Agr. Res. Tohoku Univ. 31:1-10.

Zeiger, E., G.D. Farquhar, and I.R. Cowan. 1987. Stomatal function. Stanford Univ. Press, Stanford, Calif. 